\title{
Kandungan Neutral Detergent Fibre (NDF), Acid Detergent Fibre (ADF), Hemiselulosa, Lignin dan Selulosa Onggok yang Difermentasi Trichoderma reesei dengan Suplementasi $\mathbf{N}, \mathbf{S}, \mathbf{P}$.
}

\author{
Pramisti Wildany Putri, Surahmanto dan Joelal Achmadi \\ Faculty of Animal and Agricultural Sciences, Diponegoro University \\ Tembalang Campus, Semarang 50275 Central Java - Indonesia a \\ E-mail: pramistiwildany@gmail.com
}

\begin{abstract}
ABSTRAK
Penelitian ini bertujuan untuk mengetahui kandungan Neutral Detergeni Fibre (NDF), Acid Detergent Fibre (ADF), hemiselulosa, selulosa dan lignin onggok yang difermentasi Trichoderma ressei dengan suplementasi N, S, P. Penelitian menggunakan rancangan acak lengkap terdiri dari 4 perlakuan dan 5 ulangan. Perlakuan terdiri dari T0 (onggok + NSP + T. reesei 1,5\% 0 day incubation), T1 (onggok + NSP + T. reesei $1,5 \% 2$ days incubation), T2 (onggok + NSP + T. reesei $1,5 \% 4$ days incubation), T3 (onggok $+\mathrm{NSP}+\mathrm{T}$. reesei $1,5 \% 6$ days incubation). Data yang diperoleh kemudian dianalisis menggunakan analisis of variance (ANOVA), apabila terdapat pernedaan nyata maka dilanjutkan menggunakan uji Duncan. Parameter yang diamati yaitu kandungan NDF, ADF, hemiselulosa, selulosa dan lignin. Hasil penelitian menunjukkan bahwa fermentasi onggok menggunakan Trichoderma reesei dengan suplementasi N, S, P berpengaruh nyata terhadap kandungan NDF, selulosa dan lignin $(\mathrm{P}<0,05)$ namun tidak berpengaruh terhadap kandungan ADF dan hemiselulosa $(\mathrm{P}>0,05)$.
\end{abstract}

Kata Kunci : NDF, ADF, Hemiselulosa, Selulosa.

\begin{abstract}
This research was aimed to determine Neutral Detergeni Fibre (NDF), Acid Detergent Fibre (ADF), hemicellulose, lignin and cellulose contents of onggok fermented by Trichoderma reesei with $N, S, P$ supplementation. The experimental design was a completely randomized design with 4 treatments and 5 replications. The treatments were TO (onggok $+N S P+T$. reesei 1,5\% 0 day incubation), T1 (onggok $+N S P$ $+T$. reesei 1,5\% 2 days incubation), T2 (onggok $+N S P+T$. reesei 1,5\% 4 days incubation), T3 (onggok + $N S P+T$. reesei 1,5\% 6 days incubation). Data were analyzed by using analysis of variance, when there was difference among the treatment it was continued with Duncan. The observed variable are NDF, ADF, hemicellulose, lignin and cellulolse contents. The result of the research concluded that the contents of NDF, lignin and cellulose significantly different $(P<0,05)$ but the contents of $A D F$ and hemicellulose are not $(P>0,05)$.
\end{abstract}

Keywords : NDF, ADF, Hemicellulose, Cellulose.

\section{PENDAHULUAN}

Pakan merupakan salah satu faktor penentu dalam keberhasilan usaha peternakan disamping bibit, kesehatan dan manajemen pemeliharaan. Dalam industri peternakan pakan memiliki biaya produksi yang lebih tinggi dibandingkan dengan komponen lainnya. Upaya yang dapat dilakukan untuk mengurangi tingginya biaya pakan yaitu dengan melakukan pemanfaatan hasil samping pertanian atau perkebunan sebagai bahan pakan alternatif. Hasil samping industri pertanian atau perkebunan yang dapat dimanfaatkan sebagai bahan pakan alternatif salah satunya onggok.

Onggok merupakan hasil samping dari pengolahan argoindustri tepung tapioka yang masih mengandung karbohidrat dan protein (Ari et al., 2014). Onggok mengandung serat kasar yang di dalamnya terdapat selulosa, hemiselulosa dan 
lignin yang merupakan bagian terbesar dari komponen polisakarida non pati. Pemanfaatan onggok sebagai pakan ternak masih memiliki beberapa kendala yaitu rendahnya kandungan protein dan tingginya serat kasar. Kandungan nutrien dalam onggok kering diantaranya kadar air

$16,55 \%$, protein $2,88 \%$, lemak $1,09 \%$, abu $6,16 \%$, serat kasar $34,58 \%$ dan pati $38 \%$ (Wijayanti et al., 2012). Penerapan teknologi fermentasi onggok sebagai pakan ternak diharapkan dapat meningkatkan kandungan protein dan menurunkan kandungan serat. Fermentasi dilakukan dengan memanfaatkan mikroba berupa Trichoderma reesei.

Peranan Trichoderma reesei dalam proses fermentasi yaitu mendegradasi selulosa dan pati menjadi protein dengan menghasilkan enzim selulolitik (Fransistika et al., 2012). Selain menghasilkan enzim selulolitik kapang dari golongan Trichoderma mampu menghasilkan enzim xyloglukagonik yaitu enzim yang berfungsi untuk mempermudah enzim selulolitik dalam mendegradasi selulosa dan pati (Gunam, 2011). Penambahan suplementasi yang diperlukan untuk pertumbuhan kapang saat proses fermentasi yaitu urea $[\mathrm{CO}(\mathrm{NH} 2) 2]$ sebagai sumber $\mathrm{N}$, amonium sulfat [(NH4)2SO4] sebagai sumber $\mathrm{S}$ dan sodium bifosfat cair [NaH2PO4 + 12H2O] sebagai sumber P. Penambahan suplementasi pada proses fermentasi yaitu sebagai sumber nutrien dan metabolisme bagi Trichoderma reesei agar tumbuh secara optimal. Sumber N yang berasal dari protein dimanfaatkan oleh kapang untuk pertumbuhan dan metabolisme. Hal ini dikarenakan kapang merupakan organisme hemoorgantrotof dan memperleh nutrisinya secara absorbsi dengan bantuan enzim ekstraseluler yang terdiri dari pretoelitik, amilolitik, lipotok dan selulolitik untuk memecah biomolekul kompleks berupa protein, karbohidrat dan lemak menjadi monomernya. Monomer protein, karbohidrat dan lemak yang terbentuk kemudian akan diasimilasi menjadi sumber karbon dan energi untuk selanjutnya dimanfaatkan untuk proses pertumbuhan dan metabolisme kapang.

Penelitian tentang pemanfaatan mikroorganisme berupa kapang dalam proses fermentasi pakan telah banyak dilakukan dan menunjukkan adanya pengaruh positif terhadap peningkatan kandungan nutrien. Hal ini dikarenakan adanya peningkatan aktivitas enzim selulolitik yang dihasilkan oleh Trichoderma reesei dalam mendegradasi selulosa dan pati (Safaria et al., 2013).

\section{MATERI DAN METODE}

Penelitian dilaksanakan bulan September 2018Januari 2019 dan terbagi dalam 4 tahap yaitu tahap persiapan, tahap pelaksanaan, pengambilan data dan analisis laboratorium. Penelitian dilaksanakan di Laboratorium Ilmu Nutrisi dan Pakan Fakultas Peternakan dan Pertanian Universitas Diponegoro, Semarang. Materi yang digunakan yaitu onggok kering sebanyak 3,750 kg, akuabides, Trichoderma reesei, urea [CO(NH2)2], amonium sulfat [(NH4)2SO4], sodium bifosfat cair [NaH2PO4 + $12 \mathrm{H} 2 \mathrm{O}]$, aluminium foil dan $\mathrm{pH}$ stick. Peralatan yang digunakan meliputi fermentor untuk tempat fermentasi onggok, plastik cor dan lakban untuk membungkus fermentor, kapas dan kawat jaring untuk lubang fermentor, kabel NYA untuk rak tabung fermentor dan lampu bohlam untuk pemanas dalam fermentor, nampan untuk meletakkan onggok di dalam fermentor, kompor dan teko untuk sumber pemanas saat proses penguapan serta autoklaf untuk sterilisasi onggok. Bahan yang digunakan dalam analisis laboratorium yaitu larutan $\mathrm{ADF}$, larutan $\mathrm{NDF}$, natrium sulfit [Na2SO3], aseton, akuades, dan $\mathrm{H} 2 \mathrm{SO} 4$ pekat. Peralatan yang digunakan yaitu timbangan analitik kapasitas 300 gram dengan ketelitian 0,0001 gram, oven listrik, tanur listrik, kompor listrik, pompa vakum, kertas minyak, gelas beker, crusible dan eksikator.

.Tahap persiapan dimulai dengan menyiapkan onggok sebanyak $3,750 \mathrm{~kg}$ kemudian dikeringkan selama 2 hari di bawah sinar matahari. Analisis kandungan nutrien onggok meliputi analisis bahan kering, protein kasar, sulfur dan fosfat. Pembuatan fermentor menggunakan bilah bambu dan ditutup rapat dengan plastik cor, kemudian dilakukan sterilisasi menggunakan metode penguapan air panas hingga mencapai kelembaban $90 \%$. Tahap perhitungan starter Trichoderma dan sumber N, S, P yang akan ditambahkan ke dalam substrat.

Tahap pelaksanaan yaitu perlakuan berupa inkubasi yang berlangsung selama 6 hari. Setelah proses inkubasi, sampel ditimbang untuk dianalisis di laboratorium. Tahap pengambilan data dilakukan sesuai waktu perlakuan yaitu hari ke-0, ke-2, ke-4 dan ke-6. Tahap analisis laboratorium berlangsung selama 6 minggu dan dilaksanakan di Laboratorium Ilmu Nutrisi dan Pakan, Fakultas Peternakan dan Pertanian Universitas Diponegoro, Semarang. Analisis yang dilakukan meliputi analisis kandungan bahan kering menggunakan metode Proksimat, analisis kandungan NDF, ADF, hemiselulosa, lignin dan selulosa menggunakan metode Van Soest. 
Penelitian menggunakan metode Rancangan Acak Lengkap terdiri dari 4 perlakuan dan 5 ulangan. Adapun taraf perlakuan tersebut adalah

T0 : Onggok, T. reesei + N, S, P Inkubasi 0 hari T1 : Onggok, T. reesei $+\mathrm{N}, \mathrm{S}, \mathrm{P}$ Inkubasi 2 hari

T2 : Onggok, T. reesei $+\mathrm{N}, \mathrm{S}, \mathrm{P}$ Inkubasi 4 hari

T3 : Onggok, T. reesei $+\mathrm{N}, \mathrm{S}, \mathrm{P}$ Inkubasi 5 hari

Hasil penelitian berupa nilai tengah diuji menggunakan analisis ANOVA, apabila hasil menunjukkan pengaruh nyata $(\mathrm{P}<0,05)$ maka dilanjutkan menggunakan Uji Duncan pada taraf 5\% (Steel dan Torrie, 1995).

\section{HASIL DAN PEMBAHASAN}

Parameter yang diuji dalam penelitian ini meliputi kandungan Neutral Detergent Fibre (NDF), Acid Detergent Fibre (ADF), hemiselulosa, lignin dan selulosa disajikan pada Tabel :

Tabel 1. Data kandungan fraksi serat onggok fermentasi.

\begin{tabular}{lllll}
\hline Parameter (\%) & T0 & T1 & T2 & T3 \\
\hline NDF & $33,6772^{\mathrm{b}}$ & $35,1952^{\mathrm{a}}$ & $33,8219^{\mathrm{b}}$ & $30,6375^{\mathrm{c}}$ \\
ADF & 29,9630 & 32,3406 & 31,2936 & 29,0455 \\
Hemiselulosa & 3,7141 & 2,8546 & 2,5282 & 1,5921 \\
Selulosa & $25,1296^{\mathrm{ab}}$ & $28,0037^{\mathrm{a}}$ & $26,4655^{\mathrm{ab}}$ & $23,4493^{\mathrm{b}}$ \\
Lignin & $4,8405^{\mathrm{b}}$ & $4,3677^{\mathrm{b}}$ & $4,8099^{\mathrm{b}}$ & $5,5594^{\mathrm{a}}$ \\
\hline
\end{tabular}

Superskrip yang berbeda pada baris yang sama menunjukkan perbedaan nyata $(\mathrm{P}<0,05)$.

\section{Neutral Detergent Fibre (NDF)}

Berdasarkan hasil analisis ragam fermentasi onggok menggunakan Trichoderma reesei dengan suplementasi N, S, P pada waktu inkubasi yang berbeda yang terdapat pada Tabel 1. menunjukkan adanya pengaruh nyata terhadap kandungan NDF $(\mathrm{P}<0,05)$. Hal ini disebabkan karena selama proses inkubasi Trichoderma reesei menghasilkan enzim selulase yang mendegradasi selulosa dan lignin yang merupakan bagian dari NDF.

Kandungan NDF cenderung menurun selama inkubasi, meskipun pada perlakuan T1 mengalami peningkatan jika dibandingkan dengan T0. Terjadinya peningkatan kandungan NDF pada perlakuan T1 disebabkan karena pada awal fermentasi, kapang aktif menggunakan nutrien dalam substrat untuk pertumbuhan. Karena struktur tubuh kapang terdiri dari dinding sel, maka terjadi penambahan serat pada onggok oleh dinding sel kapang (Djaya et al., 2016). Faktor lain yang menyebabkan tingginya kandungan NDF pada awal fermentasi yaitu Trichoderma reesei terlebih dahulu mencerna amilum sebelum mendegradasi selulosa. Degradasi NDF oleh Trichoderma reesei semakin tinggi diperoleh pada perlakuan T3. Penurunan kandungan NDF selama proses inkubasi disebabkan oleh adanya aktivitas kapang dalam mencerna komponen dinding sel. Sesuai dengan pendapat Crampton dan Haris (1969) bahwa menurunnya kandungan NDF bahan pakan yang memperoleh perlakuan fermentasi dikarenakan adanya penurunan komponen dinding sel yaitu hemiselulosa yang mudah dicerna oleh mikroba.

\section{Acid Detergent Fibre (ADF)}

Hasil analisis ragam fermentasi onggok menggunakan Trichoderma reesei dengan suplementasi N, S, P pada waktu inkubasi yang berbeda yang tertera pada Tabel 1. tidak signifikan. Hal ini disebabkan oleh aktivitas kapang selama proses inkubasi cenderung mencerna fraksi yang lebih mudah larut seperti amilum dan hemiselulosa sebelum mendegradasi selulosa. Sesuai dengan pendapat Sukarti et al., (2012) yang menyatakan bahwa saat awal proses fermentasi Trichoderma reesei lebih dahulu memanfaatkan fraksi mudah larut untuk memenuhi kebutuhan hidup pokok dan pertumbuhan, sehingga pada awal fermentasi kandungan di dalam onggok seperti lignin dan selulosa yang bersifat sukar larut belum terdegradasi oleh enzim selulase.

Penurunan kandungan ADF selama fermentasi yang terjadi pada perlakuan T3 disebabkan karena adanya perombakan dinding sel menjadi komponen yang lebih sederhana menjadi glukosa dan larutnya sebagian dari dinding sel dan hemiselulosa dalam larutan deterjen asam pada saat proses pemanasan, sehingga terjadi peningkatan porsi ADS (Acid Detergent Solution) dan diikuti penurunan porsi ADF. Faktor lain yang mempengaruhi penurunan kandungan ADF onggok yaitu terjadinya pemutusan ikatan lignoselulosa yang tersusun dari komponen hemiselulosa, lignin 
dan selulosa oleh mikroba. Sesuai dengan pendapat Setiawan et al., (2014) penurunan kandungan ADF bahan pakan setelah diberi perlakuan fermentasi dengan mikroba terjadi karena adanya pemutusan ikatan lignoselulosa yang komponennya terdiri dari lignin, selulosa dan hemiselulosa akibat aktivitas mikroba yang terus berkembang selama proses fermentasi.

\section{Hemiselulosa}

Hasil analisis ragam fermentasi onggok menggunakan Trichoderma reesei dengan suplementasi N, S, P pada waktu inkubasi yang berbeda yang terdapat pada Tabel 1. tidak menunjukkan adanya pengaruh nyata terhadap kandungan hemiselulosa $(\mathrm{P}>0,05)$.

Kandungan hemiselulosa onggok yang difermentasi cenderung mengalami penurunan seiring lamanya inkubasi. Penurunan kandungan hemiselulosa terjadi karena hemiselulosa memiliki sifat lebih mudah larut jika dibandingkan dengan selulosa. Menurut Van Soest (1982) komponen serat kasar berupa hemiselulosa memiliki sifat mudah dicerna oleh mikroba jika dibandingkan dengan selulosa. Penurunan kandungan hemiselulosa selama inkubasi menunjukkan adanya proses hidrolisis hemiselulosa menjadi manosa dan glukosa yang bersifat mudah larut sehinga dapat digunakan oleh kapang sebagai sumber nutrien untuk pertumbuhan. Jaelani et al., (2008) menyatakan bahwa selama berlangsungnya proses fermentasi, akan terjadi peristiwa degradasi komponen polisakarida mannan menjadi oligosakarida ditandai dengan adanya penurunan kandungan hemiselulosa.

\section{Selulosa}

Berdasarkan hasil analisis ragam fermentasi onggok menggunakan Trichoderma reesei dengan suplementasi N, S, P pada waktu inkubasi yang berbeda yang terdapat pada Tabel 1. menunjukkan adanya perbedaan nyata pada tiap perlakuan dan berpengaruh terhadap kandungan selulosa.

Produksi enzim selulase merupakan tahap dihasilkannya enzim dari proses fermentasi onggok akibat dari metabolisme Trichoderma reesei. Perolehan kandungan selulosa yang rendah pada perlakuan T3, sesuai dengan peranan Trichoderma reesei dalam proses fermentasi yaitu dapat memecah selulosa menjadi komponen yang lebih sederhana berupa glukosa dengan memanfaatkan enzim selulase yang dihasilkan. Menurut Hatta et al., (2014) keberadaan enzim selulase yang dihasilkan oleh mikroorganisme selulolitik pada proses fermentasi akan mempermudah proses pemecahan selulosa menjadi komponen glukosa. Faktor lain yang menyebabkan rendahnya kandungan selulosa pada perlakuan T3 yaitu kandungan $\mathrm{ADF}$ onggok hasil fermentasi yang cenderung menurun selama inkubasi. Semakin rendah kandungan ADF dalam suatu bahan pakan, maka akan menyebabkan semakin rendah pula kandungan selulosa dikarenakan selulosa merupakan bagian dari ADF. Kenaikan kandungan selulosa pada perlakuan T1 dan T2 disebabkan oleh kemungkinan adanya kandungan pati yang tidak terlarut saat proses pemanasan sehingga terukur menjadi selulosa. Sesuai dengan pendapat Naufala dan Pandebesie (2015) yang menyatakan bahwa pati yang tidak ikut terlarut dalam proses pemanasan akan terhitung sebagai selulosa.

\section{Lignin}

Berdasarkan hasil analisis ragam fermentasi onggok menggunakan Trichoderma reesei dengan suplementasi N, S, P pada waktu inkubasi yang berbeda yang terdapat pada Tabel 1. menunjukkan adanya pengaruh nyata terhadap kandungan lignin $(\mathrm{P}<0,05)$. Hal ini ditandai dengan adanya penurunan kandungan lignin pada awal masa inkubasi.

Penurunan kandungan lignin pada awal masa inkubasi disebabkan karena onggok pada perlakuan T1 telah mengalami proses fermentasi sejak awal inkubasi, sehingga terjadi perenggangan ikatan lignohemiselulosa dan lignoselulosa oleh enzim selulase yang dihasilkan kapang Trichoderma reesei. Sesuai dengan pendapat Naufala dan Pandebesie (2015) fermentasi bahan pakan bertujuan untuk memecah ikatan kompleks lignoselulosa menjadi selulosa dan selanjutnya dipecah kembali menjadi glukosa oleh enzim selulase. Berbeda dengan tujuan fermentasi untuk menurunkan kandungan lignin onggok agar diperoleh kecernaan yang tinggi, pada penelitian ini kandungan lignin onggok fermentasi justru mengalami kenaikan yaitu pada perlakuan T2 dan T3. Faktor yang mempengaruhi kenaikan kandungan lignin yaitu Menurut Pielhop et al. (2015) penyebab kenaikan kadar lignin yaitu terbentuknya lignin semu yang terukur menjadi lignin yang disebabkan karena terjadinya ikatan silang antara polisakarida dengan ester.

\section{KESIMPULAN}

Fermentasi onggok menggunakan starter berupa Trichoderma reesei dengan suplementasi N, $\mathrm{S}$, P memberikan pengaruh yang nyata terhadap kandungan NDF, lignin dan selulosa namun tidak memberikan pengaruh nyata terhadap kandungan ADF dan hemiselulosa.

\section{REFERENSI}

Ari, I. N., S. Tantalo dan Liman. 2014. Survei sifat fisik dan kandungan nutrien onggok terhadap metode pengeringan yang berbeda di dua 
Kabupaten Provinsi Lampung. J. Ilmiah Peternakan Terpadu. 2(2) : 58-62.

Crampton, E. W. Dan L. E. Haris. 1969. Applied Animal Nutrition 1st Ed. The Engsminger Publishing Company. California, USA.

Djaya, M. S., S. Dharmawati dan A. Nursalam. 2016. Tingkat penggunaan Trichoderma sp dalam fermentasi pelepah sawit terhadap kandungan lignin, adf dan ndf pada lama penyimpanan yang berbeda. J. Budidaya Tanaman Perkebunan Politeknik Hasnur. 2(2) : 67-72.

Fransistika, R., N. Idiawati dan L. Destiarti. 2012. Pengaruh waktu fermentasi campuran Trichoderma neesei dan Aspergillus Niger terhadap kandungan protein dan serat kasar ampas sagu. J. Kajian Komunikasi. 1(1) : 3539.

Hatta, U., O. Sjofjan dan B. Sundu. 2014. Pengaruh fermentasi kombinasi jamur Plourotus ostreatus dengan Trichoderma viridae terhadap kandungan nutrien dan aktivitas enzim selulase bungkil kopra. J. Ilmu-Ilmu Peternakan 24(2) : 20-30.

Jaelani, A. W. G. P., Suharyadi dan I. Rahayu. 2008. Hidrolisis bungkil inti sawit (Elaeis guneensis Jacq) oleh kapang Trichoderma reesei sebagai pendegradasi polisakarida mannan. Animal Production. 10(1) : 42-49.

Naufala, W. A., dan Pandebesie, E. S. 2015. Hidrolisis eceng gondok dan sekam padi untuk menghasilkan gula reduksi sebagai tahap awal produksi bioetanol. J. Teknik ITS. 4(2) : 109113.

Pielhop, T., G. O. Larrazabar, M. H. Studer, S. Brethauer, C. M. Seidal dan P. R. Von Rohr.
2015. Lignin repolymerisation in spruce autohydrolysis pretreatment increase cellulase deactivation. Green Chemistry Article Online Journal.

Safaria, S., N. Idiawati dan T. A. Zaharah. 2013. Efektivitas campuran enzim selulase dari Aspergillus niger dan Trichoderma reesei dalam menghidrolisis substrat sabut kelapa. J. Kimia Khatulistiwa. 2(1) : 46-51.

Setiawan, G., T. Dhalika dan Mansyur. 2016. pengaruh penambahan mikroba lokal (MOL) terhadap kadar neutral detergent fiber dan acid detergent fiber pada ransum terfermentasi. J. Unpad. 3(2) : 1-11.

Steel, R. G. D. dan Torrie, J. H. 1995. Prinsip dan Prosedur Statistika Suatu Pendekatan Biometrik. Catatan Ke-4. PT. Gramedia Pustaka Utama, Jakarta (Diterjemahkan Oleh B. Sumantri).

Sukarti, E., B. Sulistiyanto dan S. Mukodiningsih. 2012. Kualitas serat limbah pertanian dan hasil samping pertanian yang difermentasi dengan Aspergilus niger pada aras dan lama pemeraman yang berbeda. J. Animal Agriculture. 1(2) : 77-85.

Van Soest P. J. 1982. Nutritional Ecology of the Ruminant : Ruminant Metabolism, Nutritional Strategies the Cellulolytic Fermentation and the Chemistry of Foragesand Plant Fibers. Cornell University O \& B Books Inc. USA.

Wijayanti, D. K., C. Lestari dan M. T. Mulyanto. 2012. Pengaruh overliming pada pembuatan etanol dari limbah pabrik tepung tapioka (onggok) dengan hidrolisis asam dan enzim. J. Teknik POMITS. 1(1) : 1-3. 